\author{
Еразмо Бранковски \\ Православни Богословски факултет \\ Универзитета у Београду \\ e-mail:erazmo.brankovski95@gmail.com
}

\title{
ТУМАЧЕЊЕ ПОСЛАНИЦЕ ФИЛИПЉАНИМА У ЕГЗЕГЕЗИ ТЕОДОРА МОПСУЕСТИЈСКОГ
}

Апстракт: Теодор Мопсуестијски је био најистакнутији представник теолошке егзегетске школе у Антиохији. Као представник тзв. „друге“ генераиије антиохијских егзегета, заједно са Диодором Тарсијским и Јованом Златоустим, он је утврдио историјски метод тумачена Светог Писма као доминантан у хришћанксој васељени. Његова метогдологија заснива се на чистом историзму, са једва приметним траговима било каквог коришћења александријског алегоризма. Његове методе тумачења су непосредно утищале на истицање представника треће генерачије антиохијских егзегета, оличених у Теодориту Кирском и Несторију. Антиохијски стриктни историзам Мопсуестијског индиректно ће довести до несторијанске јереси и посредно истицање александријског алегоризма као егзегетске противтеже антиохијској егзегези.

Кључне речи: Теодор Мопсуестијски, Антиохијска школа, егзегеза, историјско тумачење, Посланииа Филипљанима.

Теолошко и егзегетско деловање Теодора Мопсуестијског (352-428) оставило је велики траг у историји Цркве и умногоме утицало на историјско-теолошке токове црквене историје. Предмет овог рада неће бити Теодорово догматско завештање, већ његов егзегетски рад као најистакнутијег представника Антиохијске егзегетске школе. У том циљу издвојиће се селективни делови Теодоровог опширног егзегетског опуса како би се представиле његове методе тумачења Светог Писма. Изабрани тумачени спис Теодора Мопсуестијског који је централна тема рада биће Посланица Филипљанима Светог апостола Павла. Настојаће се да се кроз коментаре на Теодорово тумачење поставе у главним тезама методолошке одлике тумачења Антиохијске школе. Такође ће се у погледу тумачења Теодора Мопсуестијског назрети формирање његових богословских ставова, како је као ученик антиохијске школе своје богословске ставове градио стриктно према егзегетским методама Антиохије.

\section{Теодор Мопсуестијски - кратка историјска анализа}

Теодор Мопсуестијски рођен је око 350-352. године у Мопсуестији, у провинцији Киликији ${ }^{1}$ (или у Антиохији) ${ }^{2}$. Као младић у Антиохији је изучавао реторику код

1 Јевтић 2016, 579.

2 Kannengiesser 2006, 799. 
тадашњег најпознатијег ретора, Ливанија. Био је пријатељ Светог Јована Златоустог, са којим је предводио антиохијску егзегетску хришћанску мисао 4. и 5. века. ${ }^{3}$ Око 369. године обојица су били ученици Диодора Тарсијског, који се сматра оснивачем Антиохијске школе. Замонашио се при манастиру Аскитарија, који је био под утицајем монашких правила Василија Великог, које је Теодор усвојио. Године 392. хиротонисан је за епископа града Мопсуестије. У читавој Цркви био је познати библиста, те су неки од његових најпознатијих ученика три важне личности црквене историје: Теодорит Кирски, Несторије и Руфин. Теодор Мопсуестијски је био поборник Никејско-Цариградског исповедања, те се током читавог богословског деловања борио против антиникејских јереси. Његова дела управљена су против Арија, Павла Самосатског, Аполинарија и Евномија.

Овај хришћански мислилац и егзегета је пореклом био Киликијац, културолошки ближе одређен Сиро-палестинској мисли. Ово је умногоме допринело конституисању његовог егзегетског начела. Био је веома резервисан по питању формирања хришћанске богословске мисли у терминолошко-контекстуалним токовима јелинске философије. За живота имао је добар однос са Григоријем Богословом и Кирилом Александријским, који ће га, после смрти, осудити за несторијанство. ${ }^{4}$

Буквалистичко историјско-филолошко тумачење Новог Завета удаљило је Теодора од неких догми Цркве, додуше, за његова живота још увек непотврђених на Васељенским саборима. Ипак је он у својим делима Против Македонијеваиа, О Светоме Духу, Катихезе ${ }^{5}$, изложио и бранио хришћанске истине од тадашњих јереси, пре свих аријанства, савелијанства и духоборства. Историјски тренутак његовог богословског деловања радикално је заокренуо његов богословски легат. Наиме, за живота Теодор је био поштован као борац против јереси, у својим делима одлазећи и предалеко у истицању Христове човечности, те негирању Првородног греха као извора смрти ${ }^{6}$. По његовој смрти, над Црквом се надвила сенка Несторијеве јереси, која је негирала јединство Христове божанске и човечанске природе. Како је Несторије неоспорно био Теодоров ученик, његова осуда се пренела постхумно ${ }^{7}$ и на Теодора, у чијим се делима могло наћи семе несторијанства. Тако је Теодор Мопсуестијски, од славног ретора и егзегете који је за живота бранио учење Цркве, после смрти осуђен на Петом васељенском сабору 553. године. ${ }^{8}$ Теодор Мопсуестијски је умро 428. године, оставши осуђен од стране Православне Цркве. Његов егзегетски супротстављен брат у епископству, Кирило, одбио је да осуди Теодора на пакао, поштујући чињеницу да је Теодор умро у миру са Црквом, осудивши само нека његова дела.

\section{Теодор Мопсуестијски као тумач Светог Писма}

Антиохијска егзегетска школа је, заједно са Александријском, једна од две доминантне философско-теолошке школе хришћанског истока. Антиохијска херменеутика је појам који обухвата методе тумачења Светог Писма у светлу просемитске, те историјско-наративне методе. ${ }^{9}$ Темељи учења Антиохијске школе заснивају се на историјском тумачењу Светог Писма, у покушају да се спречи (или само ограничи) утицај

3 Јевтић 2016, 579.

4 Јевтић 2016, 580.

5 Исто, 580.

6 Исто, 581.

7 Kannengiesser 2006, 801.

8 Исто.

9 Fairbairn 2007, 2. 
јелинске философије на мисао Цркве. Антиохијска школа је узрочно-последично заснована да би се супротставила Оригену, који је у тадашње теолошке токове уводио много од јелинских философских елемената, претећи тако да хришћанска философија, оличена у поруци Светог Писма, терминолошки и формативно, али и концептуално утоне у мистицизам и јелинство.

Тако су истакнути представници ове школе, Диодор Тарсијски, Теодор Мопсуестијски, Јован Златоусти, те Несторије, потенцирали значај тумачења Новог Завета кроз историјски Стари Завет. Ово је било дијаметрално супротно Александријској школи и Филону, њеном најистакнутијем представнику, који су Нови Завет проучавали кроз алегоријску вредност Старог. ${ }^{10}$ Иако сам термин историјског (ібторєко́v) није био јасно дефинисан ни од једног представника Антиохијске школе, историјско тумачење је антипод алегоријском и представљало је основно начело антиохијске егзегезе. ${ }^{11}$ Антиохијска школа је у правом смислу утемељитељ неколико најважнијих херменеутичких метода истраживања Светог Писма: историјско-критичке, литерарне, контекстуалнонаративне.

Управо је историјска егзегеза главна одлика Теодора Мопсуестијског као тумача. Теодор Мопсуестијски је писао егзегетске коментаре на скоро све књиге Светог Писма. Теодор се при тумачењу Старог Завета користи само текстом Септуагинте, слепо прихватајући језичка решења грчког језика. ${ }^{12}$ Његова тумачења Псалама, Малих пророка и Књиге Постања су репрезентативни при представљању Антиохијске егзегетске школе. Теодор се користи историјским контенстуализмом, као врсни познавалац историјских прилика описаних у књигама Старог Завета. Sitz im leben ${ }^{13}$ је доминантан као историјскореалистички контекст тумачења.

Конфронтација Теодора Мопсуестијског са Александријском школом огледа се у одређењу и тумачењу Месијанских псалама. Основна начела његове егзегезе приказаће се на примеру четири Месијанска псалма. Он одређује само Пс 2; 6; 16; 68; као Месијанске и Христолошке, док Пс 54 прихвата само као секундарно Месијански, док примарни значај даје конкретном историјском тумачењу. ${ }^{14}$ Псалам 72 је општеприхваћен у хришћанској мисли као христолошки, док га Теодор Мопсуестијски одређује као историјски, контекстуализовавши га према Соломону и периоду благостања у Јудејском Царству у његово доба. ${ }^{15}$ Сваки период спасења људског рода треба тумачити посебно, јер сваки има своје место у реалној историјској стварности. ${ }^{16}$ Теодор се и у свом тумачењу књига 12 малих пророка држи историјске егзегезе, често дајући предност историјском тумачењу наспрам христолошког. ${ }^{17}$

Теодор се држи христолошког тумачења само на основу потврде вишег ауторитета - Новог Завета. Поменути Псалми су по његовом поимању примарно христолошки само на основу њиховог цитирања у Новом Завету од стране апостола. ${ }^{18}$ Теодор ипак не одбацује потпуно алегоријско тумачење, већ прави јасну дистинкцију: тумачени део Светог Писма може се тумачити само на један начин, алегоријски или

10 Исто.

11 Kannengiesser 2006, 213.

12 Tyng 1931, 299.

13 Ерминевтичко одређење животног контекста писања као централног појма тумачења текста.

14 Tyng 1931, 300.

15 Исто.

16 Mopsuestijski 2004. 32.

17 Tyng 1931,300 .

18 Исто, 301. 
историјско-критички. ${ }^{19}$ Он пак, прави својеврсну дистинкцију између Старог и Новог Завета, посматрајући први као старо доба, а потоњи као ново. ${ }^{20}$ Не дозвољава међусобну историјску везу као неупитну. Због тога је мало есхатолошких и христолошких тумачења Старог Завета кроз Нови. При тумачењу Новог Завета Теодоров опус је неупоредиво већи, из више разлога:

- Теодор Мопсуестијски је или врло слабо или уопште није познавао јеврејски језик, те му је семитска језичко-философска мисао била страна;

- Његова тумачења Старог Завета су само историјска тумачења, док су тумачења Новог Завета имала улогу у Теодоровом теолошком сукобу са тадашњим јересима: аријанством, аполинарством, духоборством;

- Као изразити представник Антиохијске школе придавао је пуну пажњу Христовој историчности као Бога и Човека - средству формирања богословске мисли свог доба.

Теодор Мопсуестијски је коментарисао све књиге Новог Завета, док су целовито сачувана само његова тумачења Павлових посланица, у латинском преводу. ${ }^{21}$ Велики опус његове христолошке мисли заступљен је у тумачењу Јовановог Јеванђеља. Кључни део Јеванђеља је према Теодору Јн 1,14а: И Логос постаде тијело и настани се међу нама. У сукобу са Аполинаријем, који отворено негира Христову човечност, негирајући постојање људске душе у Христовој човечанској природи, ${ }^{22}$ Теодор иде радикално далеко; он заступа становиште да је Оваплоћени Логос узео себи тело - уселио се у већ зачетог човека, сјединивши се са њим. ${ }^{23}$ Христос је једно са Богом Оцем, а узевши себи тело (човек), узети човек постаје једно са Богом. ${ }^{24}$ Овако се Христова људска природа доводи у нераскидиву заједницу са Богом Оцем, тим пре потврдивши своје реално присуство у појму Оваплоћеног Христа. Узети човек постаје узвишен, задобивши прави дар синовства. ${ }^{25}$

Теодорова тријадологија, христологија, али и пневматологија је условљена његовим буквалним тумачењем Писма. У 16. поглављу своје 9. омилије, Теодор тумачи 1Кор 12,13. и Еф 4, 4-6. дословно се ослањајући на Павлов текст, те преносећи истину о Једном Богу Тројици. Лица Свете Тројице су истоветна (по природи) ${ }^{26}$, у основи нестворена, те се тако одређују као заједница насупрот створеног света. ${ }^{27}$ Теодор узима себи приличну слободу тумачења у односу на колективну егзегетску мисао Цркве. Следујући своје становиште о јединству али и независности Христа Логоса од узевшег човека, Теодор заступа тезу о нужној одвојености Логоса од човека, што је према мишљењу потоњих Васељенских сабора и отаца Цркве, омогућило развитак несторијанске јереси. ${ }^{28}$

Генерално посматрано, Теодорова егзегеза је више управљена против алегоризма, него што по сваку цену заступа историјско тумачење. Теодор сматра

19 Исто, 303.

20 Fairbairn 2007, 7.

21 Kannengiesser 2006, 802

22 Kofsky, Ruzer 2013, 64.

23 Kofsky, Ruzer, "Anthropology and Soteriology“, 64.

24 Fairbairn 2007, 6.

25 Kofsky, Ruzer 2013, 65.

26 Теодор није стриктно разликовао појмове личности и природе, те је његова тријадологија подложна и несторијанској, али и халкидонској редакцији.

27 Mopsuestijski 2004. 77.

28 Пучкова 2016, 36. 
алегоријско тумачење последицом уплива јелинске философије у хришћанску мисао. ${ }^{29}$ Следујући апостола Павла који се на више места негативно изјашњава о јелинској философији, Теодор своја тумачења управља оспоравању потенцијалних алегоријских елемената тумачења Новог Завета.

Коментари Теодора Мопсуестијског на Посланицу Филипљанима изложиће се у наредном поглављу као филолошко-историјска тумачења појединих места, како би до изражаја дошла његова историјско-критичка метода тумачења.

\section{Посланица Филипљанима}

Посланица Филипљанима била је веома заступљена као егзегетски материјал међу представницима Антиохијске школе. Сачувана су тумачења Јована Златоустог, Теодорита Кирског и Теодора Мопсуестијског. ${ }^{30}$ При тумачењу Посланице Филипљанима Теодора Мопсуестијског, треба обратити пажњу на два фокуса тумачења: индивидуални и корпусни. Индивидуални фокус тумачења усмерен је на тумачење саме Посланице у контексту развоја Теодорове богословске мисли, забележене у његовим Омилијама. Треба истаћи да су омилитичка и епистоларна књижевност у антици биле нераскидиво повезане. Тако је база омилитчке књижевности од јелинских философа, преко Отаца Цркве, до средњег века, управо остала епистоларна књижевност. ${ }^{31}$ Управо из овог разлога Мопсуестијски придаје већи значај тумачењу Павлових посланица него тумачењу Јеванђеља. Корпусни фокус је усмерен на тумачење Посланице кроз друге Павлове посланице, јер је Теодор исцрпно тумачио управо Павлове посланице, и то је његово једино потпуно сачувано егзегетско дело. Извор који је коришћен при излагању Теодоровог тумачења Посланице Филипљанима су његови коментари на Павлове посланице, у редакцији Хернија Свита из 1882. године, као основни извор тумачења. ${ }^{32}$ У склопу корпусног тумачења Павлових посланица, Теодор Мопсуестијски је покушао да датира све посланице. Он смешта настанак посланице директно у Рим ${ }^{33}$, за време Павловог првог сужањства. ${ }^{34}$

Он наглашава да се Павлово прво сужањство завршило пуштањем из тамнице, након његове одбране пред царем Нероном (2Тим. 4,16). ${ }^{35}$ Одељак из 2Тим Теодор подупире читавом 28. главом Дела Апостолских, у којима се описује Павлов боравак у Риму који се не завршава смрћу. ${ }^{36}$ Према Мопсуестијском, Павле је после две године ропства (имао је засебну кућу у којој га је чувао један преторијанац ${ }^{37}$ ), наставио мисионарско путовање у Шпанију. Оно што прво запада за око при анализи Теодоровог тумачења је општа пракса хришћанских егзегета да помену оце од којих су позајмили

29 Kannengiesser 2006, 805.

30 Silva 1992, 26.

31 Ђорђевић 2017, 448-449.

32 EpP. 198.15.

33 Исто.

34 Lanier 2002, 2.

35 John T. Curran S. J. "Tradition and the Roman origin of the captivity", Theological Studies Volume 6 issue 2, (1945.) 174.

36 Lanier 2002, 3.

37 Гај Октавијан Цезар Август је 27. године пре Христа оформио преторијанску гарду, легијску јединицу која је штитила цара и обезбеђивала улице Рима. Преторијанска гарда је била једина војна јединица која се смела кретати у Риму под оружјем. Још у доба Републике је Римљанима забрањено да улазе у престоницу као војници. Јединице Римског гарнизона пре оснивања преторијанске гарде нису улазиле у стандардни војни ратни поредак римске војске. 
одређена тумачења или целе катене. У закључку тумачења Посланице Филипљанима

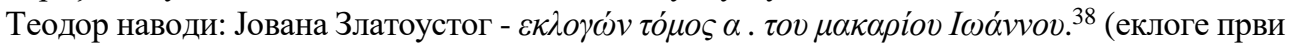
том блаженог Јована), затим Јована Севриана. Теодорови коментари се односе на читаву Посланицу, коју он ближе одређује литерарно-историјски. Кроз поглавље ће бити издвојено неколико места које је Теодор протумачио, а која представљају антиохијску херменеутику.

Битно је поменути Теодоров лични афинитет према Павлу. Он сматра Павла оснивачем Цркве у Ефесу, за разлику од свог садруга (такође представника Антиохијске егзегетске школе) који сматра апостола Јована оснивачем Цркве у Ефесу. ${ }^{39}$ Стога је интенција анализе Павлових списа не толико да се утврди историчност, већ да се узвелича Павлова мисија у свету. ${ }^{40}$

(Фил. 1,1) Павле и Тимотеј, слуге Исуса Христа, свима светима у Исусу Христу који су у Филипима, са епископима и Ђаконима:

Уводни поздрав апостола Павла у првом стиху посланице донео је филолошко одређење термина епископ и Ђакон, где се Теодор у многоме поклапа са Златоустим. ${ }^{41}$ Наиме, Теодор прави јасну дистинкцију између епископа и ђакона, иако је према неким хришћанским језичким решењима позне антике, могло бити конверзије појмова епископа, презвитера и ђакона. ${ }^{42}$ Теодор одбацује могућност конверзије, с тим што истиче блиску повезаност појмова епископа и ђакона. У пракси античке Цркве, чак и у 5. веку када је епископат досегао зенит раста своје власти у односу на презвитере, била је уобичајена пракса да се епископ обраћа презвитеру као сабрату. ${ }^{43}$

Није се напустила мисао да је епископ у основи само највиши од презвитера. Теодоров коментар потврђује суштинску истоветност појмова, док се ђакони третирају засебно. У овом одељку Теодор се супротставља и заступљеној тенденцији читања біेv

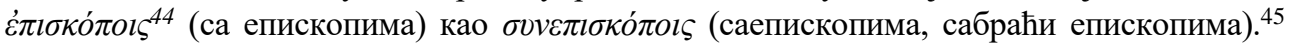
Његова тенденција према историјском тумачењу поново долази до изражаја. Он прибегава буквалном историјском тумачењу, притом раздвајајући јасно свештене службе, ${ }^{46}$ али и пренебежући еклисиолошко тумачење овог одељка, према коме се Павле и Тимотеј по служби поистовећују са епископима. Xрuста.

(Фил. 1,13) Тако да сав цүарски суд и сви остали знају да сам у оковима за

Српски превод овог стиха употребљава синтагму ичарски суд за грчки извор $\tau \tilde{\omega}$ $\pi \rho \alpha \imath \omega \rho i \omega$. Сама реч је етимолошки латинског порекла - praetōrium, praetōrī̄, n. У изворном латинском означава главни штаб или генералски шатор. Међутим, римско друштво је у периоду раног царства тежило да очува привид континуитета са Републиком и њеним друштвено-административним установама, те је милитаризација државе избегавана како на терену, тако и у лингвистичким токовима.

38 Навођење Јованове еклоге показује Теодорову потврду егзегетске праксе древне Цркве, прихватањем тумачења другог оца, али и посебан однос који је имао са Златоустим.

39 Curran 1945, 175.

40 Исто.

41 Lightfoot 1878, 230.

42 Исто, 98.

43 Исто.

44 Грчки текст Новог Завета коришћен у раду је New International Version, преузет са сајта: Google, "Interlinear Bible" https://biblehub.com/interlinear

45 Smith 2003, 34.

46 EpP. 200.5.10. 
Преторијум је имао и значење царске палате, како су римски цареви тог доба још увек били принцепси, односно први грађани. Тако је у друштвеном контексту, који се ради демилитаризације свести грађана морао уподобити невојничким језичким тумачењима ${ }^{47}$, преторијум означавао дом принцепса, или било коју већу вилу. Теодор јасно имплицира да апостол Павле под преторијумом мисли на царску палату. ${ }^{48}$ Јасно наглашава да Павле није био спроведен у команду преторијанске гарде, те се преторијум није могао односити на војни објекат, већ цивилни. ${ }^{49}$ Ово виђење поткрепљује сам Павлов однос према Риму као Јудејца. Наиме, у пограничним провинцијама царства, римски цар није био познат као принцепс, већ као император, заповедник римске војске. Зато су погранични народи имали милитаристичко виђење царства и самог цара. Павле није изузетак, што тврди и Мопсуестијски. ${ }^{50}$

(Фил. 1,22-26) Али ако је живљење у тијелу плодоносно за моје дјело, онда не знам ита да изаберем. А обузима ме обоје: имам жељу умријети и са Христом бити, цтто је много боље; Али остати у тијелу потребније је вас ради. И ово поуздано знам, да ћу остати и боравити са свима вама за ваш напредак и радост вјере, Да би се похвала ваша у Христу Исусу умножила преко мене када вам опет дођем.

Ово је једно од места где Теодор пренебегава историјско тумачење и прибегава алегоријском. Он заступа становиште да апостол Павле не мисли на телесни повратак у Филипе, већ на сједињење с њима у дан Васкрсења. Такође, ово место Теодор интерпретира као место опште поруке Цркви, ${ }^{51}$ а не само заједници у Филипима. Апостолово обећање поновног доласка усмерено је на целу Цркву. ${ }^{52}$ Теодор истиче и Павлову поруку Филипљанима о сврсисходном животу и смрти у Христу. Сам Павле не истиче шта је боље, већ оставља Филипљанима да размишљају о томе, како Теодор примећује. ${ }^{53}$

(Фил. 4,2) Еводију молим, и Синтихију молим, да исто мисле у Господу.

Теодор Мопсуестијски истиче Павлову велику љубав према Филипљанима, пред којима отворено моли две жене да пређу преко својих проблема. Павле као апостол, говорник и римски грађанин с једне стране, али и поштовани (некадашњи) фарисеј и учитељ јудејског закона, налази као важно да од свих проблема у Филипљанској Цркви помене сукоб Еводије и Синтихије. Еводија и Синтихија су биле истакнуте чланице Цркве у Филипима, можда ђаконисе. ${ }^{54}$ Теодор тумачи ову Павлову молбу као универзалну молбу одржавања мира међу хришћанима. ${ }^{55}$ Конкретан историјски тренутак обраћања апостола Павла овим двема женама довољно је утицао на Теодора да истакне историјски контест тумачења овог стиха, насупрот васељенској поруци за целу Цркву. Такође, Теодор потенцира Павлове изјаве о понизности и јединству као историјски устројене. Наиме, Теодор износи могућност да је Павлово страдање (заточеништво) могло бити један од узрока нарушавања односа између Еводије и Синтихије. ${ }^{56}$

47 Lightfoot $1878,100$.

48 Lightfoot 1878, 100.

49 EpP., 207.5.

50 Lightfoot 1878, 102.

51 EpP. 212. 10.

52 Smith 2003, 66.

53 Исто, 68.

54 Lightfoot 1878, 158.

55 Constable, 106.

56 Smith 2003, 144. 


\section{Фил 2,6-11}

Тежиште Теодорове теологије садржано је у Фил 2,6-11, христолошкој химни која умногоме утиче на обликовање његове богословске мисли. Рашчлањивањем овог одељка анализираће се тумачење Теодора Мопсуестијског упоредо са развитком његове теолошке мисли. Интересантно је истаћи да ни Теодор ни Јован Златоусти, иако су говорили и сиријски и грчки, нису препознали химничну вредност овог одељка, већ га само тумачили у наративу историјско-критичких коментара. ${ }^{57}$

6. Који будући у обличју Божијем, није сматрао за отимање то што је једнак са Богом,

Главно тежиште Теодорове егзегетске мисли је христологија. У покушају да одбрани Никејски Символ Вере од аријеваца и Аполинарија, Теодор Мопсуестијски истиче дистинкцију између Христове божанскости и људскости ${ }^{58}$. У својој осмој омилији, он истиче да је Христос Логос који је једно са Богом, од Бога. ${ }^{59}$ Христос, човек, међутим, није једно са Богом. Христос човек бива узет као обличје од стране Христа Бога. Теодор истиче Христову божанску природу као потпуно одвојену од људске. Пошто је божанска природа Христова потекла од Оца који га је родио, она се не може сјединити са људском природом која је створена. Теодор је по сваку цену желео да оповргне аријанско учење о Христовој створености, те је истакао неспојивост превечне божанске нестворене природе и људске створене, осим кроз усиновљење (адоптионизам).

7. Него је себе понизио узевши обличје слуге, постао истовјетан људима, и изгледом се нађе као човјек;

Мопсуестијски инсистира на узимању обличја као обрасца сједињења Христове божанске и човечанске природе. Логос који узима људску природу не губи своја божанска својства, нити задобија људска. ${ }^{60}$ Човек бива адоптиран од стране Бога, ${ }^{61}$ и добија могућност да се бивајући адоптиран приведе у славу Бога Оца заједно са Христом Логосом. Обличје ( представља њену суштину. ${ }^{62}$ Тако Христос пре Оваплоћења има обличје Бога, а по Оваплоћењу обличје човека. Теодор прихвата ово становиште и историјско-критичким тумачењем поставља тезу о условној одвојености Христових природа. Два обличја (природе) се међусобно не побијају, будући да су одвојене самом онтолошком предодређеношћу: нествореног према створеном. Августиново учење о одвојености природа у Христу се поклапа са Теодором, те је приметно да је концепт условне одвојености Христових природа био познат и на западу. ${ }^{63}$ Теодоров концепт одвојености природа у Христу послужио је његовом ученику Несторију да потпуно одбаци било какво јединство Христових природа, оснивајући тако јерес несторијанства.

8. Унизио је себе и био послушан до смрти, и то до смрти на крсту,

Бог се унижава, насупрот људима који у својој грешној природи настоје да се узвисе. Теодор прави дистинкцију између Бога и човека преносећи је на историјску дистинкцију Старог и Новог Завета. Стари Завет представља човека грешног и без могућности да се кроз живот удостоји Божије милости. Нови Завет представља

57 Weymouth $2015,84$.

58 Fairbairn 2007, 7.

59 Mopsuestijski 2004. 61.

60 Пучкова 2016, 36.

61 Pierre Boucaud 2013, 311.

62 Lanier 2002, 6.

63 McGuckin 1990, 44. 
Оваплоћеног Христа, који својим безгрешним животом на земљи узвисује људску природу тако што узлази у славу Бога Оца. ${ }^{64}$ Пут човека ка спасењу је потпуно у Христовој милости и понизности коју је претрпео.

9. Зато и Њега Бог високо уздиже, и дарова му Име које је изнад свакога имена.

Уздизање Христа и даровање врховне части од стране Бога показује одвојеност Христове Божанске и људске природе. Христос Логос има превечну славу Сина Божијег, док Христос човек има славу Сина Давидовог. ${ }^{65}$ Унижавајући себе и своју славу, Христос Бог ипак надвисује Сина Давидовог у слави, будући да васкрсава из мртвих.

10. Да се у Име Исусово поклони свако кољено што је на небесима и на земљи и под земљом; 11. И, да сваки језик призна да је Исус Христос Господ на славу Бога Оияа.

У тринаестој омилији Теодор Мопсуестијски истиче још једну одлику свог богословља: икономију. Наиме, својим деловањем на земљи Господ Христос је, осим што је узео на себе људску природу, одрекао себи божанско достојанство, будући у обличју слуге. Васкрсењем из мртвих и Вазнесењем на небо Христос поново задобија божанско достојанство од Оца. Он такође призива све људе, чије је обличје (природа) сада сједињена са Тројицом у божанској слави, да верују и стреме ка Христу. Последњи стих химне Теодор наводи као кључно место при подупирању Никејског Символа. Позивајући се на ауторитет апостола Павла, Теодор поистовећује Оца и Сина као Господа, негирајући аријанско учење. Буквалним литерарним тумачењем Теодор долази до потребне аргументације у одбрани Христа као Сина Божијег и Бога у односу на христолошке јереси.

\section{Закључак}

Теодор Мопсуестијски је непобитно један од највећих егзегета ране Цркве. Његова тумачења Светог Писма су успоставила методологију егзегезе Антиохијске егзегетске школе. Теодор Мопсуестијски је читавог живота водио теолошке полемике са јеретицима, бранећи Никејски Символ Вере. Његова историјско-критичка анализа допринела је аргументованом побијању аполинаризма, аријанства и евномијанства. Са друге стране, претерано слободно тумачење и недовољна дефинисаност појединих црквених израза допринели су стварању јереси несторијанизма. Иако за живота није осуђиван за јеретичко деловање, Теодор Мопсуестијски је својим егзегетским радом допринео стварању несторијанске и монофизитске кризе у историји Цркве. Његово тумачење посланице Филипљанима пружа увид у концепцију антиохијског егзегетског фокуса: животни контекст историјског тренутка који је описан у Светом Писму посматра се као примаран. Поједина места у посланици Филипљанима Теодор тумачи тако да омогући увид читаоцима у историјску вредност Новог Завета као сведочанства икономијског Христа. Алегоријска тумачења су секундарна, и Теодор их жестоко оспорава осуђујући елементе јелинске философије у њима. У тумачењу христолошке химне у Фил. 2, 6-11 Теодор истиче елементе адопционизма и посебно диафизитства. Теодоров егзегетски легат послужио је уобличавању теолошке мисли Јована Златоустог и Августина, који су управо следовали теорији одвојености Христових природа. Као тумач Новог Завета, Теодор Мопсуестијски полази од корпусне егзегезе преко индивидуалних тумачења, истичући притом апостола Павла и апостоле као врховне ауторитете формирања христолоших истина.

64 Fairbairn 2007, 10.

65 Mopsuestijski 2004. 61. 


\section{Библиографија}

Примарни извори:

Ћирилички:

Свето Писмо (2014): Издање Комисије Светог Архијерејског Синода Српске Православне Цркве. Уредник Епископ бачки Иринеј (Буловић). Београд.

\section{Латинички:}

New Testament, New International Version, Google, "Interlinear Bible" https://biblehub.com/interlinear

Mopsuestijski, Teodor (2004): Katihetske omilije. Zagreb: Kršćanska sadašnjost d.o.o. Theodori episcopi Mopsuestini in Epistolas B. Pauli Commenatarii. Vol. I (1880): ed. Henry B. Swete, Cambridge.

Секундарна литература:

Ћириличка:

Ђорђевић, Марко (2017): Епистолографија као реторички и књижевни жанр, Црквене студије 14, Ниш.

Јевтић, Атанасије (2016): Патрологија 2. Београд-Требиње-Лос Анђелес.

Пучкова, Софья Сергеевна (2016): „Огласительнье гомилии” Феодора Мопсуестийского: история публикации текста и особенности содержания, Вестник ПСТГУ. Серия I: Богословие. Философия. Религиоведение Вып. 4 (66).

\section{Латиничка:}

Boucaud, Pierre (July 2013): The Corpus Paulinum: Greek and Latin Exegesis of the Epistles in the First Millennium, Revue de l'histoire des religions Volume 230, 3.

Constable, Thomas L. Notes on Philippians, 2021 Edition (unpublished).

Curran S. J, John T. (1945): Tradition and the Roman origin of the captivity, Theological Studies Volume 6 issue 2.

Fairbairn, Donald (2007): Historical and theological studies - Patristic exegesis and Theology: The Cat and the Horse, WTJ 69.

Kannengiesser, Charles (2006): Handbook of Patristic Exegesis - The Bible in Ancient Christianity. Brill-Leiden-Boston.

Kofsky, Aryeh; Ruzer, Serge (2013): Anthropology and Soteriology in Theodore of Mopsuestia's Commentary on John, ASE 30/1.

Carolina.

Lanier, David E. (2002): An Assessment of Philippians 2:5-11. Wake Forest, North

Lightfoot, Joseph B. (1878): The Epistles of St Paul III: The first Roman captivity: Epistle to the Philippians I. London.

McGuckin, John (1990): Did Augustine's Christology depend on Theodore of Mopsuestia?, HeyJ XXXI. Leeds: University of Leeds, Department of Theology.

Silva, Moisés (1992): Philippians. Grand Rapids, Michigan: Baker Academic, a division of Baker Publishing Group.

Smith, Yancy (2003): Discourse analysis and consolation in Philippians. Ablien: Abilene Christian University.

Tyng, Dudley (1931): Theodore of Mopsuestia as an Interpreter of the Old Testament, Journal of Biblical Literature 50.

Weymouth, Richard J. (2015): The Christ-Story of Philippians 2:6-11: Narrative Shape and Paraenetic Purpose in Paul's Letter to Philippi. Otago. 


\section{Erazmo Brankovski}

\section{INTERPRETATION OF THE EPISTLE TO THE PHILIPPIANS IN THE EXEGESIS OF THEODORE OF MOPSUESTIA}

Theodore of Mopsuestia was the most prominent representative of the theological exegetical school in Antioch. As a representative of the so-called. The "second" generation of Antiochian exegetes, together with Diodorus of Tarsus and John Chrysostom, established the historical method of interpreting the Holy Scriptures as dominant in the Christian universe. His methodology is based on pure historicism, with barely noticeable traces of any use of Alexandrian allegory. His methods of interpretation directly influenced the emphasis of the representatives of the third generation of Antiochian exegetes, embodied in Theodoret of Cyrus and Nestorius. Antiochian strict historicism of Mopsuestian will indirectly lead to Nestorian heresy and indirect emphasis on Alexandrian allegory as an exegetical counterweight to Antiochian exegesis. 